\title{
Poverty Reduction, Environmental Protection and Ecosystem Services: A Prospective Theory for Sustainable Development
}

\author{
ZHEN Nahui, FU Bojie, LU Yihe, WANG Shuai \\ (State Key Laboratory of Urban and Regional Ecology, Research Center for Eco-Environmental Sciences, Chinese Academy of Sci- \\ ences, Beijing 100085, China)
}

\begin{abstract}
Poverty reduction and environmental protection are two global tasks for sustainable development. The study perspective has changed over time, from narrowly focusing on poverty reduction to comprehensively strengthening human-welfare. We reviewed key references targeting the theoretical content and practical approach relying on poverty, environment protection and ecosystem services. We discussed the contradicting views on the relationship of poverty and environmental degradation, and then illustrated the study progress of a cutting-age topic-ecosystem services which pave a way to address poverty reduction and environmental protection together. At last, we investigated essential factors that affect the development and environmental protection. Considering the evolution of the concept of poverty, we found that the environment has occupied an increasing proportion in the cognizance of poverty. The relationship between poverty and environmental degradation is regional uniqueness. In practical aspect, projects based on the management and valuation assessment of ecosystem services draw researchers' attention all over the world. The appropriate scale, essential economic incentives, morality, law and social equality are key factors affecting individuals' decisions which directly relate to the sustainable development.
\end{abstract}

Keywords: poverty; environmental degradation; ecosystem services; sustainable development

Citation: Zhen Nahui, Fu Bojie, Lu Yihe, Wang Shuai, 2014. Poverty reduction, environmental protection and ecosystem services: A prospective theory for sustainable development. Chinese Geographical Science, 24(1): 83-92. doi: 10.1007/s11769-014-0658-5

\section{Introduction}

Environmental protection and economic development pose major tasks and challenges for humans whose livelihoods and development are dependent on the environment and natural resources (Daily, 1997; Gentilini and Webb, 2008; Roe, 2008).

In the past 50 years human interference to the terrestrial ecosystems has reached an unprecedented level with the population explosion (Sadik, 1988; Palmer and Di Falco, 2012). Tilman (1999) forcast that global food production needs to be doubled to feed $9 \times 10^{9}$ people by 2030 . Similarly, areas under grain production have to increase to meet the growing consumption (Palmer and Di Falco, 2012) although cultivated land already occu- pies a quarter of earth's terrestrial surface (Hassan et al., 2005). In fact, more than $1.3 \times 10^{7}$ ha of land is being converted to agricultural use every year, mainly from forests (FAO, 2002). Such intense conversion of the land by human has brought severe consequences to the terrestrial ecosystems with equally far-reaching impacts on human well-being. For example, the Millennium Ecosystem Assessment (MA) (2005) reported that 15 of the 24 global ecosystem services have become overused or degraded, especially the ecosystem services related with land use.

It is widely accepted that poverty and environmental quality are linked problems. The Food and Agriculture Organization (FAO) (2011) stated that about $40 \%$ of degraded land is located in high poverty-stricken areas,

Received date: 2013-03-28; accepted date: 2013-07-19

Foundation item: Under the auspices of National Natural Science Foundation of China (No. 41230745, 41171156)

Corresponding author: FU Bojie. E-mail: bfu@rcees.ac.cn

(C) Science Press, Northeast Institute of Geography and Agroecology, CAS and Springer-Verlag Berlin Heidelberg 2014 
with $30 \%$ in moderately poor areas and $20 \%$ in slightly poor areas. Therefore, poverty reduction and environmental protection are key elements which should be tackled together in achieving global development targets (Reardon and Vosti, 1995). Clear conceptual frameworks are needed in order to combine policies in these two fields (Adams et al., 2004).

In this paper, we present a conceptual framework of linkages between poverty and the environment, tracking the survival, welfare, investment and ecological connotations of poverty in order to establish a sound basis for ensuing discussion about poverty reduction and environmental protection. Then we review evidence about the relationship between poverty and environmental degradation. The spatially dispersed nature of these studies leads to various conclusions on whether poverty is a degrading agent. The review then considers more policy-relevant discussion of ecosystem services which bridge poverty reduction and environmental protection. We not only discuss who is responsible for environmental degradation, the rich or the poor, and also consider various stakeholders, aiming to protect and maximize ecosystem services. This study succinctly spells out the market (pricing), management, moral, legal and institutional imperatives for sustainable supply of ecosystem services. Lastly, several factors that influence the effectiveness of policies and projects of sustainable development are laid out. The theory for development has changed a lot, and now does not just focus on poverty reduction but includes simultaneous consideration of environmental protection. Ecosystem services draw researchers' attention as they connect all stakeholders with both economic and ecological value and pave a way for sustainable development. This paper outlines the development of the theory and wished to provide reference for the following study.

\section{Poverty and Environment}

\subsection{Background and definitions}

Poverty is a complex subject that has multiple dimensions and various measurements (Wunder, 2001; Adams et al., 2004). Poverty can be defined as an unstable social condition due to the abnormal functioning of economic, ecological, cultural, or social systems, depriving people of the capability to adapt, live, and meet their minimum living needs (Opschoor, 2007). Commonly speaking, Non-Governmental Organization (NGO) and governments prefer to identify the poor out of total population using monetary method, such as a poverty line based on per-capita income. However, the index of poverty includes not only monetary facets (such as percapita income) but also nonmonetary facets (such as environment, health and mortality). It is a tough problem to integrate the available information of the poor to reveal poverty (Sen, 1976; Adams et al., 2004). The connotation of poverty is not static, on the contrary it has been enriched with time, especially the part correlated with environment. Initially, poverty is an original survival criterion of hunger and malnutrition. However, it is impossible to capture poverty with that single metric. Then a more complex index reflecting income, consumption level, and nutrition standards are proposed and the concept is renewed to be 'welfare poverty'. The 'welfare poverty' is constituted by narrow, financialbased indicators which may distinguish the human tragic situation from economic criterion. But it cannot account for all problems encountered when addressing the relationship between poverty and the environment (Reardon and Vosti, 1995). So Reardon and Vosti (1995) suggested a new measurement called 'investment-poverty', which incorporates the minimum investment level to halt environmental degradation and maintain or restore natural resources in the development of poverty standards as a threshold. The 'investment-poverty' is more site-specific due to labor conditions and environmental background, which is different from welfare poverty. 'Investment-poverty' supports a good perspective to investigate specific environment-poverty linkage. Agarwal and Narain (2002) assumed that, in order to study the relationship between poverty and the environment, the 'ecological poverty' must be stripped out. 'Ecological poverty' means poverty resulting from severe regional environmental conditions. Under the condition of a shortage of natural resources, people can neither access enough environmental services that are critical for living activities nor access sufficient and healthy natural resources for sustainable development. The concept of ecological poverty has been widely accepted in previous studies on the relationship between the environment and poverty, especially in mountainous region and remote areas (Chen, 2003; Samal et al., 2003; $\mathrm{Yu}, 2004)$. Considering that poverty often hits regions with environmental degradation problems, so in the fol- 
lowing section, we focus on the ecological poverty to reveal the connections between poverty and the environment.

\subsection{Relationship between poverty and environment}

It has generally been believed that poverty is closely associated with the environment (Duraiappah, 1998). Nevertheless, different ideas exist regarding the causality of poverty and environmental degradation (DFID et al., 2002). There is much evidence to confirm that poverty is the underlying cause of environmental degradation. But a flow of data argues that poverty has nothing to do with environmental degradation as well (Table 1).

\subsubsection{Poverty, driver of environmental degradation}

In regards to poverty being a major driver of environmental degradation, literatures are mainly based on the following arguments.

First, the poor depend more on natural resources. Cavendish (2000) analyzed the empirical regularities in the poverty-environment relationship of rural households with the purpose-collected panel data from Zimbabwe. Through identifying the aggregate contribution of natural resources in household's total income, he concluded that resource dependence varies systematically with income. With income rising, the share of aggregate environmental income decreases, so the poor are more resource-dependent than the rich. Samal's study also confirms this view. Samal et al. (2003) studied the role of agriculture, forests and livestock in people's life in India. They found most income of the poor was directly generated from natural resources or primary production activities derived from natural resources, such as forests, grassland, agriculture and forestry. Because of higher dependence on natural resources, together with a shortage of basic living essentials, the poor incline to over-exploit natural resources and consequently increase the vulnerability of the ecosystems. In this sense, the poor contribute more to environmental degradation than the rich.
Second, the poor have a high time preference (or low depreciation rate) which means that people focus on the immediate benefits rather than long-term development. High time preference influences poor people's environmental activities. Environmental economists have assumed that compared with rich people, it is more difficult for poor people to give up small benefits derived from marginal lands to meet their basic living needs or improve their low living standards. Moreover, the poor can not afford to wait a long time to gain economic and environmental benefits. So they incline to start production before the fallow or other land restoration projects have effect (Rozelle et al., 1997). For this reason, the poor often count on over-grazing, reducing fallow period and increasing labor quantity and intensity to maximize land production (Clay et al., 1998). This, in turn, results in over-exploitation of natural resources and reduction of land productivity.

Third, the poor have limited resources and means to implement essential activities or invest in projects to protect the environment (Murphree, 1993; Lumley, 1997). As the World Bank (1992) noted that the poor over-exploit resources for the short-term benefits but lack the capacity to restore the damaged natural resources. For example, lack of funding makes it impossible for the poor to enhance the soil productivity by investing in soil conservation or utilizing fertilizers. In some areas in Africa, due to lower soil productivity the existing land can no longer support the local people. The poor have no choice but to give up the existing grazing lands or croplands and find undeveloped land for survival. Hence, no necessary protective measures lead to a repeated and cumulative process of land degradation (Barbier, 2000).

\subsubsection{No relationship between poverty and environ- mental degradation}

The theory that poverty leads to environmental degradation has recently been challenged a lot and much evidence has been suggested against it.

Table 1 Relationship of poverty and environmental degradation

\begin{tabular}{|c|c|c|}
\hline Opinion & Evidence & References \\
\hline $\begin{array}{l}\text { Poverty, driver of environmental } \\
\text { degradation }\end{array}$ & $\begin{array}{l}\text { Greater dependence on natural resources among the poor } \\
\text { High time preference of the poor } \\
\text { Limited resources and fund shortage }\end{array}$ & $\begin{array}{l}\text { Cavendish, 2000; Samal et al., } 2003 \\
\text { Rozelle, 1997; Clay et al., 1998 } \\
\text { Murphree, 1993; Lumley, 1997; Barbier, } 2000\end{array}$ \\
\hline $\begin{array}{l}\text { No relationship between poverty } \\
\text { and environmental degradation }\end{array}$ & $\begin{array}{l}\text { No relevance between wealth and natural resources depend- } \\
\text { ence } \\
\text { Not high time preference of the poor } \\
\text { Inferior environment and resources accessed by the poor }\end{array}$ & $\begin{array}{l}\text { Agudelo et al., 2003; Swinton et al., 2003; } \\
\text { Narain et al., 2008; Khan and Khan, } 2009 \\
\text { Lumley, 1997; Moseley, 2001; } \\
\text { Reardon and Vosti, 1995; Agudelo et al., } 2003 \\
\text { Swinton and Quiroz, 2003 }\end{array}$ \\
\hline
\end{tabular}


First, the idea of the poor's greater dependence on natural resources has been refuted. Much evidence proves that the dependence of natural resources did not strictly relate with wealth. Narain et al. (2008) conducted a household survey in a semi-arid hilly region in India. Using the resource income share in total long-run income as a dependence measure to uncover the relation of different income groups and resources dependence, they found that the dependence of different income groups on different natural resources varies greatly. The public natural resources and incomes demonstrate a U-curve relationship which indicates that the poorest and richest depend significantly more on natural resources than the middle-income group. However, most of the private natural resources and incomes show an inverted U-curve relationship which means that the middle-income group have the highest degree of dependence on private natural resources. Through a household survey in Pakistan, Khan and Khan (2009) suggested that the poor have the same dependent relationship on natural resources as other income groups. In some cases, rich farmers and ranchers are more dependent on natural resources, as they generally possess more land or livestock. Although the per-unit environmental pressure from the rich is the same as that from the poor, the overall environmental impact of the rich is greater. In particular, the harm to the grassland caused by over-grazing among large ranchers is far more serious than that of the poor. As a result, compared with poor farmers and ranchers, richer farmers and ranchers bring greater pressure to the environment and natural resources (Agudelo et al., 2003; Swinton et al., 2003).

Second, higher time preference of the poor has also been challenged. Time preference is not only associated with wealth, but is also subject to the impacts of various factors such as education, age and health (Lumley, 1997). In general, time preference is lower if farmers are richer, younger, healthier, and with a better education. Through surveys in Africa, Moseley (2001) found that the poor do not always just focus on the immediate benefits, but also consider their future life. Local farmers even intentionally control and reduce family members' current nutrition intake in order to ensure future farming and production. Therefore, the private time preference is not a major factor that affects local farmers' adoption of land protection measures.

Third, the poor may have much stronger intention to restore the environment. Agudelo et al. (2003) theorized that poverty is not the direct cause of ecosystem degradation. At the mechanism level, human activities integrating the motivation of living should be resorted to for environmental degradation. Since poor people can be more aware of the fact that their life rely on the environment and natural resources, they will demonstrate a stronger motivation to protect the environment. Swinton and Quiroz (2003) conducted a multiple regression analysis of farm survey data which focused on soil erosion, soil fertility degradation, over-grazing and deforestation. They concluded that the sustainability of natural resources is not associated with poverty, but depends on management measures. For instance, the fallow actions of poor farmers help reduce soil erosion and improve soil productivity and over-grazing accelerates the degradation of ranches and loss of species. People also argue that environmental degradation is not caused by poverty because ecological poverty already exists on a large scale. In general, the quality of natural resources in remote mountainous areas is relatively inferior. The land resources occupied by the poor are often characterized by infertility, low soil productivity, and poor restoration potential. So environmental vulnerability is not caused by the users and is not linked with poverty (Reardon and Vosti, 1995).

Based on an integrated consideration of the above views and examples, even for the same natural resources, different results may be acquired in different regions. Swinton and Quiroz (2003), for instance, studied the factors of forest degradation in the Peru Plateau and revealed that the dependence of the local poor on firewood is responsible for degradation of the forest and deforestation. On the contrary, Khan and Khan (2009) found no correlation between local deforestation and poverty in Pakistan. It is generally assumed that countries facing with a heavy debt burden tend to plant more economic crops and exploit more natural resources such as fossil fuels. Through a study of 23 natural resources and economic crops, Neumayer (2005) found no definite correlation between the debt burden and resource exploitation rate. In this sense, the relationship between natural resources and poverty is related with resources background, policy, institutions, economic development style, and people's environmental activities. Moreover, knowing the specific relationship between environment and poverty is not enough to achieve sustainable devel- 
opment. Looking for effective measures to address poverty reduction and environmental protection is the promising direction.

\section{Ecosystem Services, New Perspective In- tegrating Environmental Protection and De- velopment}

The focus of poverty and environment research has gradually moved on to the 'poverty reduction and ecosystem services' issue. Ecosystem services are the benefits that human derived from ecosystems which include both utilitarian (monetary, biological) and non-utilitarian (esthetic, spiritual) values (Daily, 1997; UK National Ecosystem Assessment, 2011) and have taken center stage in the policy and practices of natural resources management. Ecosystem services serve as a bridge to integrate people and nature, especially in rural areas where the development depends more on farming, forestry, and fishing (Goldman, 2010; Sagie et al., 2013) and bring opportunities to deal with development and environmental conservation issues at the same time. An acute awareness of the value of ecosystem services and interactions among them would be helpful to maximize the utility of natural resources and pave a way to simultaneously achieve environmental protection and development.

In the study of ecosystem services, scientists mainly focus on the following aspects. The basic aspect is the classification of ecosystem services, which vary, but four broad categories have gained much recognition: provisioning services, regulating services, cultural services, and supporting services (MA, 2005). Provisioning services such as water, food, and timber are obviously familiar to people, and can be monetized in the market. However, unlike these tangible products, other ecosystem services such as regulating services and supporting services which also present huge value of our planet are subject to being overlooked partly due to their veiled economic value (Costanza et al., 1997). Since the 1990s, a growing interest in monetization and commercialization of ecosystem services has emerged (Costanza et al., 1997; Ton et al., 1998; Gómez-Baggethun et al., 2010). Views on the valuation and market application of ecosystem services are mixed to date, from warm support for using markets strategy in solving environmental problems to outright opposition of utilitarian conserva- tion practices (Engel et al., 2008; Child, 2009). Market is a powerful tool to guide people's environmental behaviors and affect human welfare (Gómez-Baggethun and Ruiz-Perez, 2011; Wu and Kim, 2012). Benefit Transfers (Plummer, 2009) and Payments for Ecosystem Services (PES) are two devices in wide use for environmental protection and poverty reduction and both of them are based on the valuation of ecosystem services. Benefits transfer means applying parameters such as economic benefits from one site (the study site) to another site (the policy site), especially for recreational uses of natural sites (Rosenberger and Loomis, 2001). However, collecting data of study site and policy site and assessing their value are not easy, because it implicates not only the biophysical character of the site, economic and social measures but also the potential changes brought by the policies (Plummer, 2009). PES programs, such as, Payment for Hydrological Environmental Services program in Mexico (Bulas, 2004), Grain to Green Project in China (Chen et al., 2012), and Environmentally Adjusted Water Tariffs and Natural Forests Conservation programs in Costa Rica (Pagiola et al., 2005), work out to be cost-effective both in poverty reduction and ecosystem services maintaining (Porras, 2002; Pagiola et al., 2005; Zilberman et al., 2008 Landell-Mills).

The management of ecosystem services is another essential factor linking nature and human. People try to maximize some intended production process or service by taking advantage of the relationships among ecosystem services without much expense of other environmental elements. It is well accepted that multiple and non-linear relationships exist among ecosystem services (Turner et al., 2003; Tallis et al., 2008). Through study on the biological structure and wave attenuation, Koch et al. (2009) found vegetation type and structure are not linear with coastal protection. Swallow et al. (2009) calculated the sediment yield and agricultural production in two basins of East Africa and concluded that different parts of the basins exhibit tradeoffs, synergies and traps among regulating services and provisioning services. In addition, the driving factors of the relationships among various ecosystem services were explained by Bennett et al. (2009) who indicated that the supply of ecosystems services and the interactions between ecosystem services are responding to the driver of changes. Based on this understanding of interactions of ecosys- 
tem services, people could enhance synergies and minimize trade-offs to get the maximum benefit without damaging the ecosystem, such as keeping the forest patches surrounding farmland to promote pollination and control pests (Ricketts et al., 2008) and maintaining the biodiversity and protecting the coast simultaneously (Koch et al., 2009). However, up to now, most these studies are limited to two ecosystem services. Understandings of the relationship among multiple ecosystem services and the mechanism of their interactions are still dim.

\section{Factors Affecting Environmental Protec- tion and Development}

Poverty reduction is designed to meet the short-term needs of the poor, while environmental protection is essential for the sustainable development of human society. Policies and projects in chasing for sustainable development have to be effective both in environmental protection and sustainable development. In this part, we summarize the following aspects which play particular roles in actual practices.

\subsection{Appreciate scale}

Scale is a notable element when conducting conserving projects. Linking results of different scales has become a major challenge in all sciences. Many environmental problems originate from the mismatch between the scale at which ecological processes occur and the scale at which decisions on them are made (Wang et al., 2013). Ecosystem services can be generated at a range of spatial and temporal scales, varying from the short term, site level to the long term, global level (Fu et al., 2013). The scale at which an ecosystem service is supplied often determines which groups may benefit from it. The relationship need not to be one-to-one. Ecosystem services generated at a particular ecological scale can be provided to stakeholders at a range of institutional scales, and stakeholders at an institutional scale can receive ecosystem services generated at a range of ecological scales (Wang and $\mathrm{Fu}, 2013$ ). Too broad scales make people think they are outsiders or powerless. For some specific regions, it is easy for people to generate a sense of responsibility and capacity regarding the local environment and living conditions. Then the government can adopt measures to encourage people to be involved in environmental protection and restoration activities and enhance their own environmental conditions and living standards (Hatfield and Job, 2001).

\subsection{Economic incentives}

Incentive measures are indispensable supplementary measures. Stakeholder participation could be motivated by multiple tools such as economic incentives, education, social morality, and even law if necessary (Jonesalters and Çil, 2011). Economic incentives have been used globally. Direct economic approaches are adopted to inspire rational activities of resource usage and maintain fairness of development, such as price policies which encourage farmers to grow environmentally friendly crops that pose little risk of soil erosion and ensure that the economic benefits of such crops would not be lower than other crops with greater environmental stress (Barbier, 2000). Farmers sometimes get paid for their actions to protect or restore public natural resources (Scherr, 2000). For instance, PES links ecosystem services users, resource protection, and ecosystem services providers, encouraging more people to participate in environmental protection by giving economic compensations to ecosystem services providers most of whom are poor (Engel et al., 2008; Wunder, 2008; Wunder and Albán, 2008; Baker et al., 2010; Yin and Zhao, 2011). Price policies and economic incentives are usually based on reliable valuation of ecosystem services and dedicated capital flow to link the service demanders and providers. It is very difficult to implement such projects on a large scale (Bohlen et al., 2009). As for the global-scale need for poverty reduction and environmental protection, it is utterly inadequate to simply undertake eco-compensation at the local scale.

\subsection{Morality and law}

Economic incentives are not always perfect measures to involve stakeholders in environmental protection. As Wang et al. (2013) pointed out that with humans increasing their global presence in both scale and intensity, it should be based on an integration of nature and society (nature-societal) or society and ecosystems (socioecosystem), which will facilitate the transition towards sustainable ecosystem services management. Market and government are not sufficient for achieving this, they suggest an integrated set of market, government, and human values to manage ecosystem services, as 
traditional, narrow, economic, political and scientific solutions alone do not adequately address the sustainable use of natural ecosystems. Researchers have found that social morality is another important factor which affects farmers' land management actions. They may adopt soil conservation measures due to moral considerations. Thus, except for depending on the economic benefits, the government needs to leverage moral restraints in order to regulate and guide the people's decision-making and environmental behaviors, urging people to take into account the public interests while seeking their individual development (Lumley, 1997; Chokor, 2004).

Economic incentives and morality do not always work, so law comes to be an obbligato part for environmental protection. For example, 'polluters pay' and 'polluters act on pollution control' have been written into law for many years in China, mandatorily involving the resources users in environmental protection. These measures not only accumulate funds for resource restoration, but also encourage stakeholders to take environmental protection principles into account before and during their activities (Fu et al., 2000).

\subsection{Social equality}

Social equality affects individuals' decisions in some way. People sometimes fail to take actions related to environmental protection due to a lack of necessary tools or approaches rather than lack of awareness of environmental protection. For example, in order to encourage farmers to participate in environmental protection efforts, helping local farmers expand their sources of livelihood, diversify their incomes, and mitigate people's uncertainty and vulnerability to natural disasters are needful for reducing land pressures. It is necessary to improve their resource availability, local environmental management capacity, and environmentally friendly technologies (Swinton et al., 2003; Muchena et al., 2005). Education level is often correlated with poverty, as the poor often lack sufficient funds to invest in education. Lack of knowledge and skills in turn deprives them of important tools to rise out of poverty (Swaminathan, 2000). Moreover, social inequality will reduce the degree of people's satisfaction with life (Jiang et al., 2012). It is essential to enhance social equity and ensure the accessibility of people in remote areas to education, health care, unemployment insurance, and other benefits for reducing poverty and increasing human well-being (Chokor, 2004; Cao et al., 2009).

Addressing poverty reduction and environmental protection issues not only needs policies but also their enforcement. Policy formulation needs to be supported by sufficient empirical evidence, and also requires enough flexibility for different circumstances. As there is no one-size-fits-all policy, it is important to understand which factors affect the specific land use or people's environmental activities in order to be clear about the properties of specific regional resources, development and investment opportunities, and technical applications. The mechanisms and factors influencing the relationship between poverty and environmental degradation would be obvious so that the government can fully leverage such factors to provide effective guidance (Muchena et al., 2005; Vignola et al., 2010).

\section{Conclusions}

Research on the relationship of poverty, environmental degradation and ecosystem services still has a long way to go. There are some ineluctable hurdles that researchers and policy makers have to face. The dimension of poverty and scale-based characteristics complicate environmental protection and poverty reduction issue, which is not only associated with the specific geographic conditions and socio-economic development models but also subject to the impacts of resource quality and other social factors such as population, resource development, and protection systems. The issue on environment and development is trans-disciplinary that involves ecological, environmental, social, economic, political, ethical, and technological aspects. For this reason, experts with different academic backgrounds need to conduct joint research, and policy makers are requested to develop policies to provide guidance and regulation for stakeholders. At the same time, wider participation among stakeholders is needed in order to gain better environmental benefits.

\section{References}

Adams W M, Aveling R, Brockington D et al., 2004. Biodiversity conservation and the eradication of poverty. Science, 306(5699): 1146-1149. doi: 10.1126/science.1097920

Agrawal A, Narain S, 2002. Community and Household Water Management: The Key to Environmental Regeneration and Poverty Alleviation. In: Marothia D K (ed.). Institutionalizing 
Common Pool Resources. New Delhi: Concept Publishing Company.

Agudelo C, Rivera B, Tapasco J et al., 2003. Designing policies to reduce rural poverty and environmental degradation in a hillside zone of the Colombian Andes. World Development, 31(11): 1921-1931. doi: 10.1016/j.worlddev.2003.06.007

Baker T R, Jones J P G, Rendón Thompson O R R et al., 2010. How can ecologists help realise the potential of payments for carbon in tropical forest countries? Journal of Applied Ecology, 47(6): 1159-1165. doi: 10.1111/j.1365-2664.2010.01885.x

Barbier E B, 2000. The economic linkages between rural poverty and land degradation: Some evidence from Africa. Agriculture, Ecosystems \& Environment, 82(1-3): 355-370. doi: 10.1016/ S0167-8809(00)00237-1

Bennett E M, Peterson G D, Gordon L J, 2009. Understanding relationships among multiple ecosystem services. Ecology Letters, 12(12): 1394-1404. doi: 10.1111/j.1461-0248.2009.01387.x

Bohlen P J, Lynch S, Shabman L et al., 2009. Paying for environmental services from agricultural lands: An example from the northern Everglades. Frontiers in Ecology and the Environment, 7(1): 46-55. doi: 10.1890/080107

Bulas J M, 2004. Implementing cost recovery for environmental services in Mexico. In: World Bank Water Week. Washington, DC: $24-26$.

Cao S X, Wang X Q, Wang G S, 2009. Lessons learned from China's fall into the poverty trap. Journal of Policy Modeling, 31(2): 298-307. doi: 10.1016/j.jpolmod.2008.09.004

Cavendish W, 2000. Empirical regularities in the povertyenvironment relationship of rural households: Evidence from Zimbabwe. World Development, 28(11): 1979-2003. doi: $10.1016 / \mathrm{S} 0305-750 \mathrm{X}(00) 00066-8$

Chen Nanyue, 2003. Study on the ecological poverty of the Chinese countryside. China Population, Resource and Environment, 13(4): 42-45. (in Chinese).

Chen X, Lupi F, An L et al., 2012. Agent-based modeling of the effects of social norms on enrollment in payments for ecosystem services. Ecological Modelling, 229(24): 16-24. doi: 10.1016/j.ecolmodel.2011.06.007

Child M F, 2009. The Thoreau ideal as a unifying thread in the conservation movement. Conservation Biology, 23(2): 241243. doi: 10.1111/j.1523-1739.2009.01184.x

Chokor B A, 2004. Perception and response to the challenge of poverty and environmental resource degradation in rural Nigeria: Case study from the Niger Delta. Journal of Environmental Psychology, 24(3): 305-318. doi: 10.1016/j.jenvp.2004. 08.001

Clay D, Reardon T, Kangasniemi J, 1998. Sustainable intensification in the highland tropics: Rwandan farmers' investments in land conservation and soil fertility. Economic Development and Cultural Change, 46(2): 351-378. doi: 10.1086/ 452342

Costanza R, d'Arge R, de Groot R et al., 1997. The value of the world's ecosystem services and natural capital. Nature, 387: 253-260. doi:10.1038/387253a0

Daily G, 1997. Nature's Service-social Dependence on Natural
Ecosystem. Washington: Island Press.

DFID (Department For International Development), EC (European Commission), UNDP (Uuited Nations Development Programme),World Bank, 2002. Linking Poverty Reduction and Environmental Management: Policy Challenges and Opportunities. Washington, DC, USA: World Bank,

Duraiappah A K, 1998. Poverty and environmental degradation: A review and analysis of the nexus. World Development, 26(12): 2169-2179. doi: 10.1016/S0305-750X(98)00100-4

Engel S, Pagiola S, Wunder S, 2008. Designing payments for environmental services in theory and practice: An overview of the issues. Ecological Economics, 65(4): 663-674. doi: 10.1016/j.ecolecon.2008.03.011

FAO (Food and Agriculture Organization of the UN), 2002. FAOSTAT Statistics Database. Rome, Italy: UN Food and Agriculture Organization.

FAO, 2011. The State of the World's Land and Water Resources for Food and Agriculture (SOLAW): ManagingvSystems at Risk. London: Food and Agriculture Organization of the United Nations, Rome and Earthscan.

Fu Bojie, Chen Liding, Yu Xiubo, 2000. The new trends and counter-measures on eco-environmental issues in China. Chinese Journal of Environmental Science, 21(5): 104-106. (in Chinese)

Fu B J, Wang S, Su C H et al., 2013. Linking ecosystem processes with ecosystem services. Current Opinion in Environmental Sustainability, 5(1): 4-10. doi: 10.1016/j.cosust.2012. 12.002

Gentilini U, Webb P, 2008. How are we doing on poverty and hunger reduction? A new measure of country performance. Food Policy, 33(6): 521-532. doi: 10.1016/j.foodpol.2008. 04.005

Goldman R L, 2010. Ecosystem services: How people benefit from nature. Environment: Science and Policy for Sustainable Development, 52(5): 15-23. doi: 10.1080/00139157.2010. 507140

Gómez-Baggethun E, de Groot R, Lomas P L et al., 2010. The history of ecosystem services in economic theory and practice: From early notions to markets and payment schemes. Ecological Economics, 69(6): 1209-1218. doi: 10.1016/j.ecolecon. 2009.11.007

Gómez-Baggethun E, Ruiz-Perez M, 2011. Economic valuation and the commodification of ecosystem services. Progress in Physical Geography, 35(5): 613-628. doi: 10.1177/030913331 1421708

Hassan R, Scholes R, Ash N et al., 2005. Ecosystems and Human Well-being: Current Sstate and Trends: Findings of the Condition and Trends Working Group. Millennium Ecosystem Assessment Series (volume 1). Washington, D.C., USA: Island Press.

Hatfield J, Job R F S, 2001. Optimism bias about environmental degradation: The role of the range of impact of precautions. Journal of Environmental Psychology, 21(1): 17-30. doi: 10.1006/jevp.2000.0190

Jiang S Q, Lu M, Sato H, 2012. Identity, Inequality, and 
Happiness: Evidence from Urban China. World Development, 40(6): 1190-1200. doi: 10.1016/j.worlddev.2011.11.002

Jones-Walters L, Çil A, 2011. Biodiversity and stakeholder participation. Journal for Nature Conservation, 19(6): 327329. doi: 10.1016/j.jnc.2011.09.001

Khan S R, Khan S R, 2009. Assessing poverty-deforestation links: Evidence from Swat, Pakistan. Ecological Economics, 68(10): 2607-2618. doi: 10.1016/j.ecolecon.2009.04.018

Koch E W, Barbier E B, Silliman B R et al., 2009. Non-linearity in ecosystem services: Temporal and spatial variability in coastal protection. Frontiers in Ecology and The Environment, 7(1): 29-37. doi: 10.1890/080126

Landell-Mills N, Porras I, 2002. Silver Bullet or Fool's Gold? A Global Review of Markets for Forest Environmental Sservices and Their Impact on the Poor. London, UK: International Institute for Environment and Development (IIED).

Lumley S, 1997. The environment and the ethics of discounting: An empirical analysis. Ecological Economics, 20(1): 71-82. doi: 10.1016/S0921-8009(96)00073-0

MA (Millennium Ecosystem Assessment), 2005. Ecosystems and Human Well-being: Our Human Planet. Washington, DC: Island Press.

Moseley W G, 2001. African evidence on the relation of poverty, time preference and the environment. Ecological Economics, 38(3): 317-326. doi: 10.1016/S0921-8009(01)00184-7

Muchena F N, Onduru D D, Gachini G N et al., 2005. Turning the tides of soil degradation in Africa: Capturing the reality and exploring opportunities. Land Use Policy, 22(1): 23-31. doi: 10.1016/j.landusepol.2003.07.001

Murphree M, 1993. Communal Land Wildlife Resources and Rural District Council Revenues. In: Centre for Applied Social Science. Harare: University of Zimbabwe.

Narain U, Gupta S, van't Veld K, 2008. Poverty and resource dependence in rural India. Ecological Economics, 66(1): 161-176. doi: 10.1016/j.ecolecon.2007.08.021

Neumayer E, 2005. Does high indebtedness increase natural resource exploitation? Environment and Development Economics, 10(2): 127-141. doi: 10.1017/S1355770X04001901

Opschoor J B, 2007. Environment and poverty: Perspectives, propositions, policies, Working Paper, ISS (437 Novomber)

Pagiola S, Arcenas A, Platais G, 2005. Can payments for environmental services help reduce poverty? An exploration of the issues and the evidence to date from Latin America. World Development, 33(2): 237-253. doi: 10.1016/j.worlddev.2004. 07.011

Palmer C, Di Falco S, 2012. Biodiversity, poverty, and development. Oxford Review of Economic Policy, 28(1): 48-68. doi: 10.1093/oxrep/grs008

Plummer M L, 2009. Assessing benefit transfer for the valuation of ecosystem services. Frontiers in Ecology and the Environment, 7(1): 38-45. doi: 10.1890/080091

Reardon T, Vosti A S, 1995. Links between rural poverty and the environment in developing countries. World Development, 23(9): 1495-1506. doi: 10.1016/0305-750X(95)00061-G

Ricketts T H, Regetz J, Steffan-Dewenter I et al., 2008. Land- scape effects on crop pollination services: Are there general patterns? Ecology Letters, 11(5): 499-515. doi: 10.1111/ j.1461-0248.2008.01157.x

Roe D, 2008. The origins and evolution of the conservationpoverty debate: A review of key literature, events and policy processes. Oryx, 42(04): 491-503. doi: 10.1017/S00306053 08002032

Rosenberger R S, Loomis J, 2001. Benefit transfer of outdoor recreation use values: A technical document supporting the Forest Service Strategic Plan (2000 revision). Gen Tech Rep RMRS-GTR-72. Fort Collins, CO: US Department of Agriculture, Forest Service, Rocky Mountain Research Station.

Rozelle S, Huang J K, Zhang L X, 1997. Poverty, population and environmental degradation in China. Food Policy, 22(3): 229-251. doi: 10.1016/S0306-9192(97)00011-0

Sadik N, 1988. 1988 State of the World Population Report: Safeguarding the Future. New York, USA: United Nations Population Fund.

Sagie H, Morris A, Rofè Y et al., 2013. Cross-cultural perceptions of ecosystem services: A social inquiry on both sides of the Israeli-Jordanian border of the Southern Arava Valley Desert. Journal of Arid Environments, 97: 38-48. doi: 10.1016/ j.jaridenv.2013.05.007

Samal P, Palni L M, Agrawal D, 2003. Ecology, ecological poverty and sustainable development in Central Himalayan region of India. International Journal of Sustainable Development \& World Ecology, 10(2): 157-168. doi: 10.1080/135045 00309469794

Scherr S J, 2000. A downward spiral? Research evidence on the relationship between poverty and natural resource degradation. Food Policy, 25(4): 479-498. doi: 10.1016/S0306-9192(00) 00022-1

Sen A, 1976. Poverty: An ordinal approach to measurement. Econometrica, 44(2): 219-231.

Swallow B M, Sang J K, Nyabenge M B et al., 2009. Tradeoffs, synergies and traps among ecosystem services in the Lake Victoria basin of East Africa. Environmental Science \& Policy, 12(4): 504-519. doi: 10.1016/j.envsci.2008.11.003

Swaminathan M, 2000. Weakening Welfare: The Public Distribution of Food in India. New Delhi: LeftWord Books

Swinton S M, Escobar G, Reardon T, 2003. Poverty and environment in Latin America:concepts, evidence and policy implications. World Development, 31(11): 1865-1872. doi: 10.1016/j.worlddev.2003.06.006

Swinton S M, Quiroz R, 2003. Is poverty to blame for soil, pasture and forest degradation in Peru's Altiplano? World Development, 31(11): 1903-1919. doi: 10.1016/j.worlddev. 2003.06.004

Tallis H, Kareiva P, Marvier M et al., 2008. An ecosystem services framework to support both practical conservation and economic development. Proceedings of the National Academy of Sciences of the United States of America, 105(28): 94579564. doi: 10.1073/pnas.0705797105

Tilman D, 1999. Global environmental impacts of agricultural expansion: The need for sustainable and efficient practices. 
Proceedings of the National Academy of Sciences of the United States of America, 96(11): 5995-6000. doi: 10.1073/ pnas.96.11.5995

Ton S, Odum H T, Delfino J J, 1998. Ecological-economic evaluation of wetland management alternatives. Ecological Engineering, 11(1-4): 291-302. doi: 10.1016/S0925-8574(98) 00039-1

Turner R K, Paavola J, Cooper P et al., 2003. Valuing nature: Lessons learned and future research directions. Ecological Economics, 46(3): 493-510. doi: 10.1016/s0921-8009(03) 00189-7

UK National Ecosystem Assessment, 2011. The UK national ecosystem assessment. In: Conceptual Framework and Methodology. Cambridge: UNEP-WCMC.

Vignola R, Koellner T, Scholz R W et al., 2010. Decision-making by farmers regarding ecosystem services: Factors affecting soil conservation efforts in Costa Rica. Land Use Policy, 27(4): 1132-1142. doi: 10.1016/j.landusepol.2010.03.003

Wang S, Fu B J, Su C H et al., 2013. Ecosystem services management: An integrated approach. Current Opinion in Environmental Sustainability, 5(1): 11-15. doi: 10.1016/ j.cosust.2013.01.003

Wang S, Fu B J, 2013. Trade-offs between forest ecosystem services. Forest Policy and Economics, 26: 145-146. doi: 10.1016/j.forpol.2012.07.014

World Bank, 1992. World Development Report. Oxford: Oxford
University Press.

Wu T, Kim Y-S, 2012. Environmental markets: concentrate on criteria. Science, 326(20): 1060. doi: 10.1126/science.326. 5956.1060-c

Wunder S, 2001. Poverty alleviation and tropical forests-What scope for synergies? World Development, 29(11): 1817-1833. doi: 10.1016/S0305-750X(01)00070-5

Wunder S, 2008. Payments for environmental services and the poor: Concepts and preliminary evidence. Environment and Development Economics, 13(3): 279-297. doi: 10.1017/ s1355770x08004282

Wunder S, Albán M, 2008. Decentralized payments for environmental services: The cases of Pimampiro and PROFAFOR in Ecuador. Ecological Economics, 65(4): 685-698. doi: 10.1016/ j.ecolecon.2007.11.004

Yin R S, Zhao M J, 2011. Ecological restoration programs and payments for ecosystem services as integrated biophysical and socioeconomic processes - China's experience as an example. Ecological Economics, 73: 56-65. doi: 10.1016/j.ecolecon. 2011.11.003

Yu Fawen, 2004. Study on ecological poverty in northwest region. China Soft Science, (11): 27-30. (in Chinese)

Zilberman D, Lipper L, McCarthy N, 2008. When could payments for environmental services benefit the poor? Environment and Development Economics, 13(3): 1-24. doi: 10.1017/ s1355770x08004294 